\footnotetext{
${ }^{1}$ Department of Ruminant Animal Science, Laboratory of Fur Animals, Agricultural University of Szczecin,

${ }^{2}$ Division of Fur and Pet Animals, Warsaw Agricultural University, Poland
}

\title{
Effect of light intensity on reproduction of Polish, Swedish, and Danish chinchillas*
}

\author{
Dedicated to Prof. Dr. Peter Horst on the occasion of his $75^{\text {th }}$ birthday
}

\begin{abstract}
The aim of this study was to determine at what level of artificial illumination the best reproduction performance can be achieved, as well as how varied light intensity affects chinchillas of different genetic groups. Reproduction performance was evaluated for 100 Polish, 52 Swedish, and 83 Danish females. Light intensity, measured with a photoelectric light meter LS-200, ranged between 0 and $100 \mathrm{~lx}$. The chinchillas were assigned to 5 groups, 20-lx interval each. The analysis included: mean litter size, mean number of weaned per litter, death rate during nursing, number of litters per female per year, as well as litter size and number of weaned per female per year. For each genetic group, the highest death rate of the young was found at the lowest light intensity level, i.e. 0-20 lx, while the lowest mortality was at 41-60 lx. Both Swedish and Danish chinchillas had lower nursing mortality at a higher level of illumination (61-100 lx), while higher mortality was recorded at lower light intensity $(0-40 \mathrm{~lx})$, compared to Polish chinchillas. It can be concluded that light intensity affects chinchilla reproduction, since higher litter sizes and reduced offspring mortality were observed under stronger light. Danish females attained the highest number of litters per year, the largest litter size and the highest number of weaned per year at the light intensity of 61-80 lx, compared to the other genetic groups. Chinchillas proved to be sensitive to very small changes in light intensity.
\end{abstract}

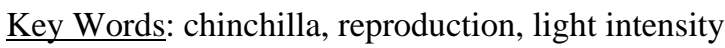

\section{Zusammenfassung}

Titel der Arbeit: Einfluss der Lichtintensität auf die Reproduktionsergebnisse der polnischen und der aus Dänemark und Schweden importierten Chinchilla

Das Ziel der Arbeit war das Herausfinden, bei welcher Kunstlichtintensität beste Reproduktionsergebnisse erzielt werden, und wie die differenzierte Lichtintensität die Chinchillas verschiedener Genotypgruppen beeinflusst. Im Versuch wurden Reproduktionsergebnisse von weiblichen Tieren bewertet: 110 polnischen (A), 52 aus Schweden (B) und 83 aus Dänemark importierten Chinchillas. Die Lichtintensität, gemessen mit Hilfe eines photoelektrischen Messgerätes LS-200, lag im Bereich von 0 bis 100 lx. Die fünf Vergleichsgruppen unterschieden sich hinsichtlich der Lichtintensität ansteigend von 20 bis 100 lx. Analysiert wurden: Zahl der geborenen und aufgezogenen Nachkommen je Wurf, Verluste bis zum Absetzen, Wurfzahl je Muttertier und Jahr, Zahl der geborenen und aufgezogenen Nachkommen je Muttertier im Jahr. In allen genetischen Gruppen wurden größte Verluste in der Gruppe mit geringster Lichtintensität (0-20 lx) festgestellt, die geringsten hingegen bei der Lichtintensität von 41 bis 60 lx. Im Vergleich mit polnischen Chinchillas (A) wiesen die aus Schweden (B) und Dänemark (C) importierten Tiere geringere Sterblichkeit in der Aufzuchtperiode bei größerer Lichtintensität (61100 lx), größere Sterblichkeit bei geringerer Lichtintensität (0-40 lx) auf. Anhand der durchgeführten Analyse kann festgestellt werden, dass die Lichtintensität die Fortpflanzung der Chinchillas beeinflusst: Mit der Steigerung der Lichtintensität stieg die Wurfgröße an und nahm die Sterblichkeit von Jungtieren ab. Die Chinchillas erwiesen sich als sehr empfindlich selbst gegenüber geringen Lichtintensitätsveränderungen. Die weiblichen Tiere aus Dänemark brachten im Vergleich mit den beiden übrigen genetischen Gruppen bei der Lichtintensität von 61-80 lx die größte Wurfzahl je Jahr $(1,33)$, größte Nachkommenzahl $(2,97)$ sowie die größte Zahl der aufgezogenen Tiere im Jahr $(2,63)$.

Schlüsselwörter: Chinchilla, Reproduktion, Lichtintensität

* Financed by the State Committee for Scientific Research, project no. KBN-3PO6Z 02623 


\section{Introduction}

In their natural environment, chinchillas inhabit mountain slopes and live a nocturnal life; however, some researchers have found them to live diurnal life as well (WALKER, 1995). In cage farms, chinchillas remain active both during the day and at night, similar to rabbits (MARAI and RASHWAN, 2003; SCHÜDDEMAGE et al., 2000; OSENI et al., 1997).

In the moderate climate of Poland, chinchillas are managed exclusively indoors, and the microclimate of the shed may affect their reproduction performance. Chinchilla reproduction functions heavily depend on temperature, humidity, and intensity of light (SULIK and FELSKA, 1999). The temperature of the sheds where females whelp should remain within the range $16-22^{\circ} \mathrm{C}$, relative humidity $50-70 \%$, and air velocity $0.2 \mathrm{~m} / \mathrm{s}$ (BARABASZ, 2001).

Chinchillas belong to polyoestrous animals and, when days become longer, they respond with enhanced sexual activity, which can be observed from December until May (GROMADZKA-OSTROWSKA, 1998). A number of factors indicate that chinchillas can be kept without access to solar light; their needs, however, in terms of artificial light intensity have not been described.

A certain level of light intensity is a signal to start or stop the synthesis of melatonin, which is also responsible for reproduction processes. Melatonin controls the synthesis and secretion of the hypothalamus hormones, which regulate the secretion of pituitary hormones responsible for ovulation (UDAŁA and BŁASZCZYK, 1999). Pineal gland stopping melatonin secretion triggers a release of the hypothalamus hormones (MALAPAUX et al., 1999). According to MEDINA et al. (1999), light intensity is a factor that affects pineal gland metabolism. Melatonin is produced in darkness, while light inhibits the process (MEDINA et al., 1999).

If electric light is the only source of illumination in a chinchilla shed, we should bear in mind that it is weaker than solar light and usually does not cover the entire visible light spectrum. Therefore, it is important to consider the following elements: light intensity level, day length, evenness of illumination of all cages, and the colour of light emitted by the lamps. At present, illumination of chinchilla farms is the same as that applied for rabbits, which most commonly consists of glow-discharge tubes of $5 \mathrm{~W} / \mathrm{m}^{2}$ (BARABASZ, 2001).

Chinchillas are usually kept in cages arranged in so called polygamous sets, i.e. four females remain in their separate, isolated cages, which are connected only by a narrow passage available for a single male. Polish breeders have noted that if chinchillas are managed in rooms lit with artificial light and a 4-storey cage arrangement is applied, females kept in the lowest cages, obtaining the lowest amount of light, displayed the worst reproduction performance (FELSKA et al., 2002). Similar conclusions were drawn by GARCIA et al. (1989).

Animals that are farmed in Poland often belong to various genetic groups, which include home-bred chinchillas born at a given farm, or those imported from other countries, most often from Denmark and Sweden. The chinchillas imported from these countries represent excellent replacement material for the breeding stock. So far, comparative studies on the reproduction performance of Polish chinchillas versus imported ones have been carried out (FELSKA and BRZOZOWSKI, 2001; SOCHA and WRONA, 2000), though light intensity of their housing has never been taken into account. 
The aim of this study was to determine an effect of light intensity on the reproduction performance of Polish chinchillas in relation to those imported from Denmark and Sweden.

\section{Material and methods}

The experiment took place at a chinchilla farm located in north-western Poland during 1998-2000. The temperature in the shed ranged between 15 and $25^{\circ} \mathrm{C}$, relative air humidity being about 60\%. Reproduction performance of standard chinchillas was analysed. The animals were allowed to mate in polygamous sets, with an average of four females per one male, the sets remaining in cages for polygamous breeding arranged in four layers. The animals were fed on balanced ration pellets and hay. Only artificial lighting was applied at the farm, produced by glow-discharge tubes of 5 $\mathrm{W} / \mathrm{m}^{2}$. Twelve-hour light regime was applied.

Table 1

Number of females, litters, born and weaned kittens by genetic group and light intensity (Zahl der weiblichen Tiere, Wurfzahl und Zahl der geborenen und aufgezogenen Nachkommen in den Jahren 1998-2000 in drei genetischen Gruppen je nach Lichtintensität)

\begin{tabular}{|c|c|c|c|c|c|}
\hline 1 & 2 & $\begin{array}{c}\text { Number of } \\
\text { females }\end{array}$ & Number of litters & $\begin{array}{l}\text { Number of born } \\
\text { chinchillas } \\
\text { during } \\
\text { 1998-2000 }\end{array}$ & $\begin{array}{c}\text { Number of } \\
\text { weaned } \\
\text { chinchillas } \\
\text { during 1998- } \\
2000 \\
\end{array}$ \\
\hline \multirow{6}{*}{ A } & $\mathrm{I}$ & 29 & 96 & 207 & 173 \\
\hline & II & 34 & 109 & 256 & 226 \\
\hline & III & 25 & 91 & 205 & 189 \\
\hline & IV & 6 & 22 & 49 & 43 \\
\hline & $\mathrm{V}$ & 16 & 45 & 82 & 70 \\
\hline & Total & 110 & 363 & 799 & 701 \\
\hline \multirow{6}{*}{ B } & I & 10 & 38 & 76 & 68 \\
\hline & II & 9 & 27 & 62 & 54 \\
\hline & III & 8 & 23 & 48 & 43 \\
\hline & IV & 10 & 40 & 89 & 79 \\
\hline & $\mathrm{V}$ & 15 & 50 & 113 & 101 \\
\hline & Total & 52 & 178 & 388 & 345 \\
\hline \multirow{6}{*}{ C } & $\mathrm{I}$ & 30 & 108 & 230 & 192 \\
\hline & II & 19 & 54 & 131 & 119 \\
\hline & III & 5 & 17 & 33 & 31 \\
\hline & IV & 15 & 53 & 113 & 104 \\
\hline & $\mathrm{V}$ & 14 & 50 & 107 & 96 \\
\hline & Total & 83 & 282 & 614 & 542 \\
\hline \multirow{6}{*}{ Total } & I & 69 & 242 & 513 & 433 \\
\hline & II & 62 & 190 & 449 & 399 \\
\hline & III & 38 & 131 & 286 & 263 \\
\hline & IV & 31 & 115 & 251 & 226 \\
\hline & V & 45 & 145 & 302 & 267 \\
\hline & Total & 245 & 823 & 1801 & 1588 \\
\hline
\end{tabular}

1) genetic group; 2) level of light intensity

The experiment allowed evaluation of reproduction performance for females of three genetic groups, i.e. (A) 110 Polish-origin, farm-bred females, (B) 52 females imported 
from Sweden, and (C) 83 females imported from Denmark. In all, 245 females at the same age (three years old when the study began) were evaluated for reproductive performance. The females had been born from the same size litters.

The cage interiors were measured for light intensity using an LS-200 photoelectric light meter. The measurements were done in the central part of a cage with the sensor directed in six planes perpendicular to each other. An arithmetic mean was calculated from the results of such six exposures at a given point. After the measurements, the females were assigned to the following groups according to light intensity of their environment: group I, 0-20 lx; group II, 21-40 lx; group III, 41-60 lx; group IV, 61-80 lx; group V, 81-100 lx.

Table 1 presents the data on the number of females in individual genetic and illumination groups, number of litters, as well as the total number of offspring born and raised by the females. The following reproductive performance indices were analysed in each group: litter size, number of young weaned per litter, number of litters per female per year, number of born and weaned chinchillas per female per year. The results were analysed statistically using the Statistica PL 6.0 software package. The statistical analysis of the reproduction parameters was done using one-way and two-way ANOVA with Duncan test. The reproduction parameters represented the dependent variables, while the genetic groups of the chinchillas and the level of light intensity were the qualitative factors. Two significance levels were applied, $\mathrm{p} \leq 0.05$ and $\mathrm{p} \leq 0.01$.

\section{Litter size}

\section{Results}

Table 2 presents the litters size in relation to light intensity and a genetic group. Should light intensity be omitted in our considerations, litter size remains at a very similar level among the genetic groups and is 2.2 in the group of Polish females and 2.18 in the group of Swedish and Danish animals.

The two-way analysis of variance did not show a significant interactions between the factors, i.e. between light intensity and genetic group. It was found that genetic group did not influence the litter size. Statistically significant differences were found in relation to light intensity. In all the groups, $\mathrm{A}, \mathrm{B}$, and $\mathrm{C}$, the largest litter sizes were recorded at the intensity of 21-40 lx (group II), i.e. 2.35, 2.30, and 2.42 young per litter respectively. Differences significant at the level $\mathrm{p} \leq 0.01$ were found between the results obtained at the light intensity 81-100 lx (group V) in the group A and those at 21-40 lx (group II) in the group C. Significant differences $(p \leq 0.05)$ were found between the results obtained at light 21-40 lx (group II) and those at 81-100 lx (group V), and between 41-60 lx (group III) and those at 81-100 lx (group V) among the Polish chinchillas (group A). Significant differences $(p \leq 0.05)$ were also found between the data obtained at light intensity 81-100 lx (group V) in Polish chinchillas (group A) and at 21-40 lx (group II) and at 81-100 lx (group V) in Swedish chinchillas (group B), and those at light 0-20 lx (group I) in Swedish chinchillas (group B) and at 21-40 lx (group II) in Danish chinchillas (group C). In the Danish group (C) the significant differences $(\mathrm{p} \leq 0.05)$ were found between the results obtained at light 21-40 lx (group II) and at light 41-60 lx (group III).

Within the Polish group, higher litter sizes were recorded at lower light intensity, 2.35 and 2.25 kittens respectively, compared with the highest light intensity (group V) at 
which 1.82 kittens were born in a litter.

No significant differences were found in the mean litter size within the group of females imported from Sweden (B). The lowest litter size in the Swedish chinchillas (group B) was found at 0-20 lx (group I), 2.00, while the highest at 21-40 lx (group II), 2.30 kitten.

Within the Danish group of females (C) the highest litter size, 2.42 kittens, was achieved at a lower light intensity, while the lowest litter size, 1.94 kittens, was obtained at a higher light intensity.

Table 2

The litter size in relation to three genetic groups and light intensity (Wurfgröße in drei genetischen Gruppen je nach Lichtintensität)

\begin{tabular}{|c|c|c|c|c|}
\hline 1 & 2 & X & S & V\% \\
\hline \multirow{6}{*}{ A } & $\bar{I}$ & 2.16 & 0.81 & 37.66 \\
\hline & II & $2.35^{\mathrm{a}}$ & 0.72 & 30.86 \\
\hline & III & $2.25^{b}$ & 0.78 & 34.76 \\
\hline & IV & 2.27 & 0.68 & 30.77 \\
\hline & V & $1.82^{\text {Aabcd }}$ & 0.75 & 41.02 \\
\hline & Total & 2.20 & 0.78 & 35.28 \\
\hline \multirow{6}{*}{ B } & I & $2.00^{\mathrm{e}}$ & 0.90 & 45.02 \\
\hline & II & $2.30^{c}$ & 0.83 & 35.86 \\
\hline & III & 2.09 & 0.60 & 28.58 \\
\hline & IV & 2.22 & 0.83 & 37.38 \\
\hline & $\mathrm{V}$ & $2.26^{d}$ & 0.80 & 35.54 \\
\hline & Total & 2.18 & 0.81 & 37.18 \\
\hline \multirow{6}{*}{ C } & I & 2.13 & 0.84 & 39.62 \\
\hline & II & $2.42^{\text {Aef }}$ & 0.96 & 39.72 \\
\hline & III & $1.94^{f}$ & 0.56 & 28.63 \\
\hline & IV & 2.13 & 0.76 & 35.67 \\
\hline & V & 2.14 & 0.78 & 36.58 \\
\hline & Total & 2.18 & 0.88 & 38.27 \\
\hline \multirow{6}{*}{ Total } & I & $2.12^{\mathrm{g}}$ & 0.84 & 39.55 \\
\hline & II & $2.36^{\text {ggh }}$ & 0.81 & 34.24 \\
\hline & III & $2.18^{h}$ & 0.73 & 33.49 \\
\hline & IV & 2.18 & 0.77 & 35.15 \\
\hline & V & $2.08^{\mathrm{g}}$ & 0.79 & 38.14 \\
\hline & Total & 2.19 & 0.80 & 36.65 \\
\hline
\end{tabular}

A, B, C - differences significant at $\mathrm{p}<0.01$

a, b, c... - differences significant at $\mathrm{p}<0.05$

1) genetic groups

2) light intensity

Analysing the mean litter size without the division into genetic groups, statistically significant $(\mathrm{p} \leq 0.01)$ differences were found between the results obtained at 21-40 lx (group II), 2.36, and those at 81-100 lx (group 5), 2.08 kittens. Significant ( $\leq 0.05)$ differences were also found between litter sizes at 0-21 lx (group I), 2.12 kittens, and at 21-40 lx (group II), as well as between those obtained at 21-40 lx (group II).

The highest mean litter size was found at the light intensity of 21-40 lx (group II), 2.36, and the lowest at 81-100 lx (group V), 2.08 kittens. 


\section{Number of weaned per litter}

As far as the mean number of young chinchillas weaned (successfully raised) from a litter is concerned, the situation was similar to that of the mean litter size.

Table 3 presents a statistical breakdown of the mean number of kittens weaned from a litter by genetic group. The two-way ANOVA did not reveal significant interactions between the two factors, i.e. light intensity and genetic group. It was found that genetic group did not significantly influence the number of weaned young per litter. Statistically significant differences were found in relation to light intensity. Significant differences ( $\mathrm{p} \leq 0.01$ ) were found between the results obtained at 81-100 lx (group A) in Polish chinchillas (A) and those obtained at 21-40 lx (group II) in the Danish chinchillas $(C)$. Statistically significant $(p \leq 0.05)$ differences were found between the results obtained at 21-40 lx (group II), 41-60 lx (group III), and those obtained at 81$100 \mathrm{~lx}$ (group V) in the group of Polish females (A). Significant differences ( $\mathrm{p} \leq 0.05$ ) were also found between the results obtained at 81-100 lx (group V) in the Polish chinchillas (A), and those obtained at 21-40 lx (group II) and at 81-100 lx (group V) in the Swedish chinchillas (B).

Table 3

The number of weaned from litter in relation to three genetic groups and light intensity (Aufgezogene Tiere je Wurf in drei genetischen Gruppen je nach Lichtintensität)

\begin{tabular}{|c|c|c|c|c|}
\hline 1 & 2 & $X$ & S & V\% \\
\hline \multirow{6}{*}{ A } & $\bar{I}$ & 1.80 & 0.76 & 42.31 \\
\hline & II & $2.07^{a}$ & 0.74 & 35.77 \\
\hline & III & $2.08^{b}$ & 0.73 & 35.33 \\
\hline & IV & 1.95 & 0.65 & 33.41 \\
\hline & $\mathrm{V}$ & $1.56^{\text {Aabcd }}$ & 0.66 & 42.37 \\
\hline & Total & 1.93 & 0.75 & 38.80 \\
\hline \multirow{6}{*}{ B } & I & 1.79 & 1.02 & 56.87 \\
\hline & II & $2.00^{c}$ & 0.83 & 41.60 \\
\hline & III & 1.87 & 0.62 & 33.46 \\
\hline & IV & 1.98 & 0.86 & 43.64 \\
\hline & $\mathrm{V}$ & $2.02^{d}$ & 0.80 & 39.36 \\
\hline & Total & 1.94 & 0.84 & 43.59 \\
\hline \multirow{6}{*}{ C } & I & 1.78 & 0.90 & 50.62 \\
\hline & II & $2.20^{\mathbf{A}}$ & 1.03 & 46.96 \\
\hline & III & 1.82 & 0.53 & 28.99 \\
\hline & IV & 1.96 & 0.78 & 39.93 \\
\hline & $\mathrm{V}$ & 1.92 & 0.75 & 39.14 \\
\hline & Total & 1.92 & 0.87 & 45.44 \\
\hline \multirow{6}{*}{ Total } & I & $1.79^{\mathrm{Be}}$ & 0.86 & 48.30 \\
\hline & II & $2.10^{\mathrm{BC}}$ & 0.84 & 40.24 \\
\hline & III & $2.00^{\mathrm{e}}$ & 0.70 & 34.80 \\
\hline & IV & 1.96 & 0.78 & 39.80 \\
\hline & V & $1.84^{\mathrm{C}}$ & 0.76 & 41.28 \\
\hline & Total & 1.93 & 0.81 & 42.15 \\
\hline
\end{tabular}


In the group of Polish females, the lowest mean number of weaned per litter was recorded at 81-100 lx (group V), 1.56 kittens, and 0-20 lx (group I), 1.80 kittens, whilst the highest number was found at the intensity of 21-60 lx (groups II and III), 2.07 and 2.08 chinchillas respectively.

Within the group imported from Sweden (B), the lowest number of weaned chinchillas was obtained at 0-20 lx (group I), 1.79, and the highest at 81-100 lx (group V), 2.02 weaned offspring, and this is the only genetic group where the highest number of weaned per litter was recorded at the highest light intensity.

Within the Danish group (C), the lowest number of weaned per litter at the light intensity 0-20 lx (group I), 1.78, and the highest number of weaned at 21-40 lx (group II), 2.20 kittens.

Table 3 shows that no significant differences occurred between the genetic groups in either litter size or mean number of weaned per litter.

Neglecting the genetic groups division, significant $(\mathrm{p} \leq 0.01)$ differences in mean number of weaned per litter were found between the light intensity 0-21 lx (group I), 1.79, and those at 21-40 lx (group II), 2.10, as well as between 21-40 lx (group II) and those at 81-100 lx (group V), 1.84 weaned kittens. Also, statistically significant $(\mathrm{p} \leq 0.05)$ differences in the mean number of weaned per litter were found at the light intensity 0-20 lx (group I) and those at 41-60 lx (group III), 2.00 kittens.

\section{Number of litters, litter size, and number of weaned per female per year}

Table 4 presents the number of litters per female of breeding stock per year. As it is shown, this number was not very high. There were no large differences between the genetic groups in the number of litters per year, and those that occurred were statistically non-significant. In individual genetic groups, this number was 1.10, 1.14, and 1.13 , respectively in the group A, B, and C.

During the studied period, the highest number of litters within the group of Polish females was found at the light intensity of 41-80 lx (group III and IV), 1.21 and 1.22 litters, in the group imported from Sweden at 61-80 lx (group IV), 1.33 litters, while in those imported from Denmark at 0-20 lx (group I), 1.20 litters, and at 81-100 lx (group V), 1.19 litters.

Such low the number of litters per year resulted in the fact that the index of annually born and weaned offspring per female was not very high as well (Table 4). Within the group of Polish females (A), the highest number of offspring born and weaned per female was achieved at the light intensity of 41-80 lx (group III and IV), 2.73 and 2.52 respectively. The lowest number, however, was recorded at 80-100 lx (group V), 1.71 and 1.42 born and weaned respectively.

Within the group of Swedish females (B), the highest number of born and weaned offspring per annum was obtained at 61-80 lx (group IV), 2.97 and 2.63 respectively, whereas the lowest at 41-60 lx (group III), 2.00 and 1.79 respectively.

In the case of Danish females (C), the highest number of born offspring per female per year was recorded at 0-21 lx (group I), 2.56, whilst the most weaned offspring at 61-80 lx (group IV), 2.31 kittens.

Should the genetic-group division be neglected, the highest annual number of born and weaned offspring per female was achieved at 61-80 lx (group IV), 2.70 and 2.43 respectively. 
Table 4

Number of litters, born and weaned chinchillas per female during 1998-2000 by genetic group and light intensity per year (Wurfzahl sowie Zahl der geborenen und aufgezogenen Chinchillas je Muttertier in drei genetischen Gruppen je nach Lichtintensität)

\begin{tabular}{|c|c|c|c|c|}
\hline 1 & 2 & $\begin{array}{c}\text { Mean number of } \\
\text { litters }\end{array}$ & $\begin{array}{l}\text { Mean number of } \\
\text { born chinchillas }\end{array}$ & $\begin{array}{l}\text { Mean number of } \\
\text { weaned chinchillas }\end{array}$ \\
\hline \multirow{6}{*}{ A } & $I$ & 1.10 & 2.38 & 1.99 \\
\hline & II & 1.07 & 2.51 & 2.22 \\
\hline & III & 1.21 & 2.73 & 2.52 \\
\hline & IV & 1.22 & 2.72 & 2.39 \\
\hline & $\mathrm{V}$ & 0.94 & 1.71 & 1.46 \\
\hline & Total & 1.10 & 2.42 & 2.12 \\
\hline \multirow{6}{*}{ B } & I & 1.27 & 2.53 & 2.27 \\
\hline & II & 1.00 & 2.30 & 2.00 \\
\hline & III & 0.96 & 2.00 & 1.79 \\
\hline & IV & 1.33 & 2.97 & 2.63 \\
\hline & $\mathrm{V}$ & 1.11 & 2.51 & 2.24 \\
\hline & Total & 1.14 & 2.49 & 2.21 \\
\hline \multirow{6}{*}{ C } & I & 1.20 & 2.56 & 2.13 \\
\hline & II & 0.95 & 2.30 & 2.09 \\
\hline & III & 1.13 & 2.20 & 2.07 \\
\hline & IV & 1.18 & 2.51 & 2.31 \\
\hline & V & 1.19 & 2.55 & 2.29 \\
\hline & Total & 1.13 & 2.47 & 2.18 \\
\hline \multirow{6}{*}{ Total } & I & 1.17 & 2.49 & 2.09 \\
\hline & II & 1.02 & 2.41 & 2.14 \\
\hline & III & 1.15 & 2.51 & 2.31 \\
\hline & IV & 1.24 & 2.70 & 2.43 \\
\hline & $\mathrm{V}$ & 1.07 & 2.24 & 1.98 \\
\hline & Total & 1.12 & 2.45 & 2.16 \\
\hline
\end{tabular}

1) genetic groups

2) level of light intensity

\section{Nursing mortality}

The Figure presents nursing mortality, i.e. percentage of young chinchillas that died during nursing. Two-way ANOVA and Duncan test did not show a significant effect of genetic group or light intensity on the mortality of the young during maternal nursing. However, both among the Polish chinchillas (A) and those imported from Denmark (C), the highest nursing mortality was found at the lowest illumination level, 0-21 lx (group I), $16.4 \%$ and $16.5 \%$ respectively. On the other hand, the group of Swedish chinchillas (B) showed the highest nursing mortality at 21-40 lx (group II), $12.9 \%$.

Within all the genetic groups, one-way ANOVA did not prove a significant difference at $\mathrm{p} \leq 0.01$ between the results obtained at the light intensity 0 -20 lx (group I), and the those obtained at 41-60 lx (group III). The lowest death rate was recorded at 41-60 lx (group III); for the group A, B, and C it was respectively 7.8\%, $10.4 \%$, and $6.1 \%$. Next, the mortality gradually increased with an increased light intensity, reaching $14.6 \%$ (A), $10.6 \%$ (B), and 10.3\% (C) at the highest illumination, i.e. at $81-100 \mathrm{~lx}$ (group V). Thus, it seems that the chinchillas imported from Sweden and Denmark 
showed lower nursing mortality at a higher light intensity, i.e. 61-100 lx, compared with the Polish animals.

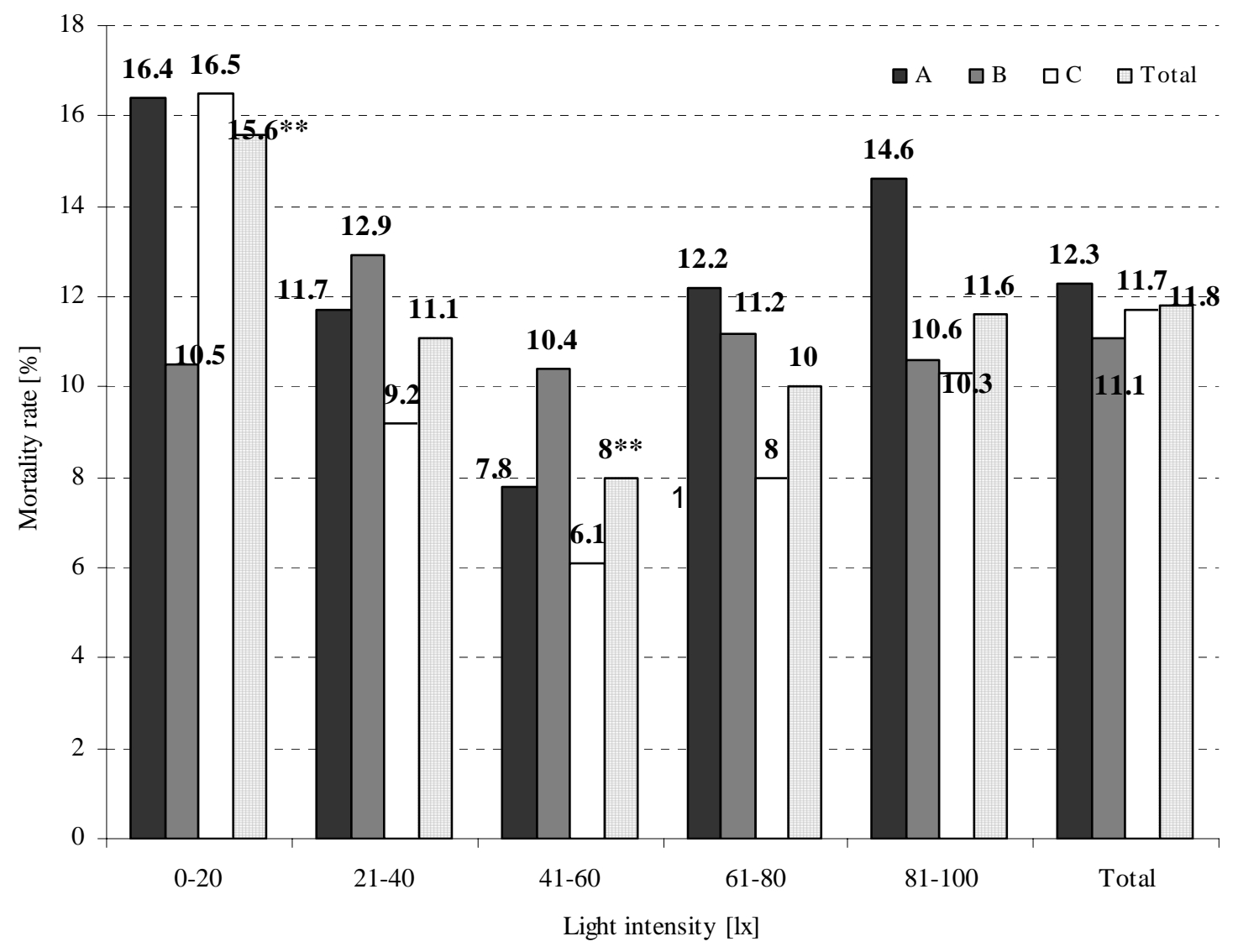

Fig.: Nursing mortality by genetic group and light intensity (Verluste in der Aufzuchtperiode in drei genetischen Gruppen je nach Lichtintensität)

\section{Discussion}

Chinchilla fecundity in Poland ranges between 2 and 2.5 kittens per litter, while as many as 4 young per litter are achieved in other countries (SULIK and BARABASZ, 1995; SOMMER, 1986). Slightly different results were reported by SOCHA and WRONA (2000), who found that local females achieved higher mean litter size, i.e. 2.11 young, as compared with imported females, which produced 1.86 kittens per litter. This may have resulted from the fact that imported females had to accommodate to their new environment. In the studied chinchillas the differences between local and imported females were not so high, since the local females produced 2.20 kittens per litter on average and those imported from Sweden or Denmark gave 2.18 and 2.19 respectively. SOCHA and WRONA (2000) found that a higher number of weaned chinchillas, 1.78, were achieved by Polish females compared to imported females, 1.55 weaned kittens. This in turn may be a result of constantly improving housing conditions of Polish farms, which is also good for chinchilla reproduction.

Our results have demonstrated that chinchillas are sensitive to even very low changes in lighting intensity, as the highest differences in mean litter size were found at as low illumination as 21-40 lx (group II). The chinchilla belongs to nocturnal species (BARABASZ, 2001), however ROLLAG et al. (1980) and SAOBOUREAU et al. 
1991) stated that hypothalamus of such animals is very sensitive to light, and as little as $200 \mathrm{~lx}$ of light is enough to inhibit melatonin secretion. On the other hand, hypothalamus of diurnal animals needs about $1,000 \mathrm{~lx}$ to stop secreting melatonin (ELORANTA et al., 1995). Such a high level of hypothalamus sensitivity to light intensity may explain large differences in litter size between groups I and II. In their natural habitat, chinchillas spend most of their time in rock nooks, crevices, or caves, where sunlight is limited, which may underlie increased litter sizes at low differences in light intensities. According to many authors, females housed in well-illuminated cages deliver and raise litters of larger sizes (GARCIA et al., 1989). It has been found in our experiment that too low the light intensity (0-20 lx), as well as too high (80-100 $\mathrm{lx}$ ) resulted in reduced litter size and weaned rate per litter.

Due to low chinchilla prolificacy, it should be reasonable to have two litters per year. The mean number of litters per female per year observed in our experiment was not high and did not exceed the level of 1.5. Other authors reported this index not higher than 1.3 (SEREMAK and SULIK, 2002).

In our studies, nursing mortality was similar to those reported by GARCIA et al. (1989) and FELSKA et al. (2002). The authors found that females delivered larger litters and nursing mortality was lower in better-illuminated cages. Our analysis also allows concluding that light intensity influences nursing mortality.

\section{Conclusions}

Statistically significant differences were found in mean litter size and weaned number within genetic groups in relation to light intensity level. The highest litter size and weaned number was found at 21-40 lx in the group of Danish chinchillas.

Light intensity elevated by 20 lx resulted in larger litter sizes, which may demonstrate that chinchilla is sensitive to very low light intensity changes.

In each genetic group, the highest number of litters per female as well as the highest annual number of born and raised offspring was achieved at 41-80 lx.

Light intensity visibly influences nursing mortality; this index reached its highest level at the lowest light intensity in all the studied genetic groups. The chinchillas imported from Sweden and Denmark showed lower nursing mortality at higher light intensity (61-100 lx), and higher mortality at lower light intensities (0-40 lx), compared with Polish-origin chinchillas.

The optimal illumination level seems 21-80 lx of light intensity.

\section{BARABASZ, B.:}

\section{References}

Chinchillas. Breeding and Management. [In Polish]. Państwowe Wydawnictwo Rolnicze i Leśne, Warszawa (2001)

ELORANTA, E.; TIMISJARVI, J.; NIEMINEN, M.; LEPPALUOTO, J.; VAKKURI, O.: Seasonal onset and disappearance in female reindeer. Am. Zool. 35 (1995), 203-214

FELSKA, L.; BRZOZOWSKI, M.:

Comparison of reproduction performance of three chinchilla genetic groups. [In Polish]. Zeszyty Naukowe Przeglądu Hodowlanego 58 (2001), 31-38

FELSKA, L.; BRZOZOWSKI, M.; RZEWUCKA, E.:

Reproduction performance of chinchilla in relation to cage level and light intensity level. [In Polish]. Zeszyty Naukowe Przeglądu Hodowlanego 64 (2002), 97-102.

GARCIA, X.; NEIRA, R. SHEN, R.:

Environmental effects on reproductive traits in confined chinchillas (Chinchilla laniger Gray). Avances Prod. Anim., t. 14 (1989) 1-2, 121-127 
GROMADZKA-OSTROWSKA, J.:

Studia nad fizjologią szynszyli ze szczególnym uwzględnieniem rozrodu i odporności. Zeszyty Naukowe AR w Krakowie 238 (1998), Professorship dissertation.

MALAPAUX, B.; THIERY, J. C.; CHEMINEAU, P.:

Melatonin and the seasonal control of reproduction. Reproduction, Nutrition, Development. 39 (1999) 3, 355-366

MARAI, F.M.; RASHWAN, A.A.:

Rabbits behaviour under modern commercial production conditions - a review. Arch. Tierz., Dummerstorf 46 (2003) 4, 357-376

MEDINA, S.; VALERO-FUENMAYOR, N.; CHACÍN-BONILLA, L.; AŇEZ, F.; GIRALDOTH, D.; ARIAS, J.; ESPINA, G.; ACHONG, A.Y.; BONILLA, E.:

Exposure to 2500 Lux increases serum melatonin in Venezuelan Equine Encephalomyelitis. Neurochemical Research 24 (1999) 6, 775-778

OSENI, S.; ODUBOTE, I.; AKINOKUN, O.; SOMADE, B.:

Productivity levels of three breeds of rabbits and their cross over a three-year period in the humid tropics. Arch. Tierz., Dummerstorf 40 (1997) 5, 469-476

ROLLAG, M.D.; PANKE, J.S.; TRAKULRUNGSI, W.K.; TRAKULRUNGSI, C.; REITER, R.J.:

Quantification of daily melatonin synthesis in the hamster pineal gland. Endocrinol. 106 (1980), 231236

SAOBOUREAU, M.B.; VIVIEN-ROELS, B. ; PÉVET, P.:

Pineal melatonin concentrations during day and night in the adult hedgehog: Effect of a light pulse at night and superior cervical ganglionectomy. J. Pineal. Res. 11 (1991), 92-98

SCHÜDDEMAGE, M.; HOY, ST.; LANGE, K.:

Einfluss von Kunst- und Naturlicht auf das Verhalten beim Absamen und die spermatologischen Parameter von Rammlern. Arch. Tierz., Dummerstorf 43 (2000) 4, 351-362

SEREMAK, B.; SULIK, M.:

Characteristics of reproduction performance parameters of chinchilla exemplified by selected farm in 1997-2000. [In Polish]. Acta Scientiarum Polonorum, Zootechnika 1 (2002) 1-2, 139-146

SOCHA, S.; WRONA, A.:

Prolificacy of chinchilla females (Chinchilla velligera Moll.) belonging to various genetic groups. [In Polish]. Zeszyty Naukowe Przeglądu Hodowlanego 53 (2000), 87-95

SOMMER, J.:

Breeding results for chinchillas. Scientifur 10 (1986) 2, 112

SULIK, M.; BARABASZ, B.:

Comparison of reproduction management systems of chinchilla exemplified by selected farms.[In Polish]. Zeszyty Naukowe AR Kraków, Zootechnika 30 (1995), 159-166

SULIK, M.; FELSKA, L.:

Effect of temperature and humidity on health condition of chinchillas.[In Polish]. Zeszyty Naukowe Przeglądu Hodowlanego 42 (1999), 137-143

UDAŁA, J.; BŁASZCZYK, B.:

Selected mechanisms regulating the course of reproduction processes in sheep and goats.[In Polish]. Medycyna Weterynaryjna 55 (1999) 11, 733-736

WALKER, E.P.:

Mammals of the World. ed. John Hopkins Press, vol. 2, III (1995), 1029-1032, Baltimore

Received: 2004-02-17

Accepted: 2005-09-14

Authors' addresses

LIDIA FELSKA-BŁASZCZYK, PhD

Department of Ruminant Animal Science

Laboratory of Fur Animals

Agricultural University of Szczecin,

Ul. Doktora Judyma 10,

71-460 SZCZECIN, POLANDＥ＿Ｅ-mail: l.felska@biot.ar.szczecin.pl

Prof. MARIAN BRZOZOWSKI, PhD DSc

Division of Fur and Pet Animals

Warsaw Agricultural University

Ul. Nowoursynowska 166

02-787 WARSZAWA, POLAND

E-mail: brzozowskim@delta.sggw.waw.pl 